Article

\title{
Social Feedback Loop in the Organic Food Purchase Decision-Making Process
}

\author{
Marko Ogorevc, Kaja Primc, Renata Slabe-Erker*, Barbara Kalar, Miha Dominko, Nika Murovec \\ and Tjaša Bartolj
}

Institute for Economic Research, Kardeljeva ploščad 17, 1000 Ljubljana, Slovenia; ogorevcm@ier.si (M.O.); Primck@ier.si (K.P.); kalarb@ier.si (B.K.); dominkom@ier.si (M.D.); murovecn@ier.si (N.M.); bartoljt@ier.si (T.B.)

* Correspondence: erkerr@ier.si

Received: 20 April 2020; Accepted: 18 May 2020; Published: 20 May 2020

\begin{abstract}
To ensure the food industry continues to grow, it is vital to properly understand the factors that impact the purchasing of organic food. Research offers ambiguous findings about what drives consumers to decide to purchase food labeled as organic. This study advances the current theories on organic food-purchasing behavior, which overlook the importance of the two-way interaction of social norms and individual behavior, suggesting that the role of social norms may have been simplified. We suggest the causal processes associated with organic food decision-making involve the social feedback loop, a powerful force that takes the current state into the phase of transition. Positive feedback is key to maintaining and developing the sustainable behavior of the society, where an initial change in consumer behavior to purchase organic food is magnified when that change resounds through social norms. This is especially pronounced in Norway and Slovenia, where marketers can make more cost- and time-efficient use of persuasive messages and requests. In addition, we provide a comprehensive delineation of organic food purchase decision-making of close to 14,000 individuals from 15 countries that includes key psychosocial antecedents, along with Schwartz's values, attitudes, social norms, perceived behavioral control, and intentions. Using a mixed-methods approach (i.e., statistical matching, spatial econometrics, structural equation modeling), the present paper thus intends to add to the understanding of environmentally friendly purchase behavior beyond unidirectional and single-theory relationships.
\end{abstract}

Keywords: organic food purchasing; Schwartz's theory; feedback loop; attitudes; intentions; social norms

\section{Introduction}

Households are a big contributor to environmental pollution and excessive natural resource use, with food consumption being one of modern society's leading unsustainable practices. Available data on foodborne diseases and climate change show the urgency of promoting sustainable food consumption and that it should be prioritized in a developed economy since it has the dual benefit of a cleaner environment and healthy living [1]. Increasing food wastes, the global imbalance in the food supply, food insecurity, excessive food miles, obesity, and diet-related diseases all signal improper dietary practices. However, the area of agriculture certified as organic has expanded considerably in recent years [2].

Although much effort has been taken to understand what drives consumers to act sustainably, the attitudinal and behavioral concepts are still considered to best explain sustainable consumption [3]. Numerous studies report that consumer attitudes to food free of chemical fertilizers, pesticides, herbicides, hormones, antibiotics, and other toxins (i.e., organic food) can help predict purchase intention and subsequent behavior [4-8]. Favorable contextual factors that strengthen the intention-behavior 
relationship are also shown to include the level of control one perceives they have concerning their actions (i.e., perceived behavioral control) [9-11]. On the other hand, the importance of the social norms construct, which denotes unwritten rules about acceptable group conduct, is underestimated in the relevant literature, partly because of its reported non-significant impact on intentional/behavioral constructs $[12,13]$. The authors explained the finding by claiming that organic food is a new concept being adopted by niche customers, meaning that social expectations have not yet sufficiently developed to support such behavior [14]. While this still might hold for developing nations, the rise in organic food consumption indicates that the norms in developed countries are recently established and may predict organic food purchasing [15].

A largely ignored property of a social norm in current studies is that it induces a feedback loop [16]: The more widely members of a social group practice a behavior, the more it becomes expected, thereby reinforcing adherence [17-19]. Bandura defines this dynamic process as reciprocal determinism. In reciprocal determinism, "personal agency and social structure operate as co-determinants in an integrated structure rather than as a disembodied duality" [16] (p. 266). By enabling an individual to alter and construct new behaviors, it may be regarded as an important mechanism [16]. Another outcome of these dynamics is that even a small change in an initial condition can introduce significant uncertainty in future predictions. As a result, the existing organic food purchase decision-making models that lack the two-way interaction of social norms and individual behavior are likely to underestimate the proposed relationships and forecasts needed in order to plan for a greener future.

As a response, we introduce a model that emphasizes the importance of the bidirectional interaction of social norms and individual behavior, together with a set of already established psychosocial determinants. The overarching research question we intend to address concerns the interplay between social norms and organic food purchasing behavior and their mutual influence on future sustainable consumption. Our model, therefore, suggests that a change in the individual's behavior affects the social norms of the group to which they belong, which, in turn, indicates future sustainable behavior. Our position is that the maintenance and development of the sustainable behavior of society relies on the identification of the feedback loop [20]. The more widespread a norm is within a group, the more strongly individuals are motivated to make it a reality [17]. A positive feedback loop is crucial for amassing the forces required for creating and sustaining an action [20,21].

Personal values is another factor used for understanding food choice behavior and directly and indirectly affects behavior via mediating concepts like attitudes and intentions [22-24]. Values are "desirable transsituational goals, varying in importance, that serve as guiding principles in the life of a person or other social entity" [25] (p. 21). The most widely used value theories are Hofstede's five-dimensional theory [26], Inglehart's theory of materialist and post-materialist values [27], Schwartz's theory of cultural value orientations [25], and Stern and Dietz's biospheric-altruistic and egoistic value orientations [28]. The latter two theories are of specific relevance to the study of food purchase behavior $[23,29]$. Therefore, we integrate Schwartz's motivational types into the model for predicting organic food purchasing by statistically matching the latest available data (for 2010). We use two databases- the International Survey Program Environmental module and the European Social Survey Wave 5-to develop the psychosocial organic food choice framework comprehensively. The next section describes the antecedents of organic food purchasing behavior captured in our framework.

\section{Construct Definition and Research Hypotheses}

Understanding the organic food decision-making process assists in predicting purchase and consumption behavior. Therefore, our model contains some conceptually independent determinants, namely the values, attitudes, perceived behavioral control, and intentions, shown to be relevant in past studies on food choice behavior, including the addition of the newly established feedback loop (Figure 1). 


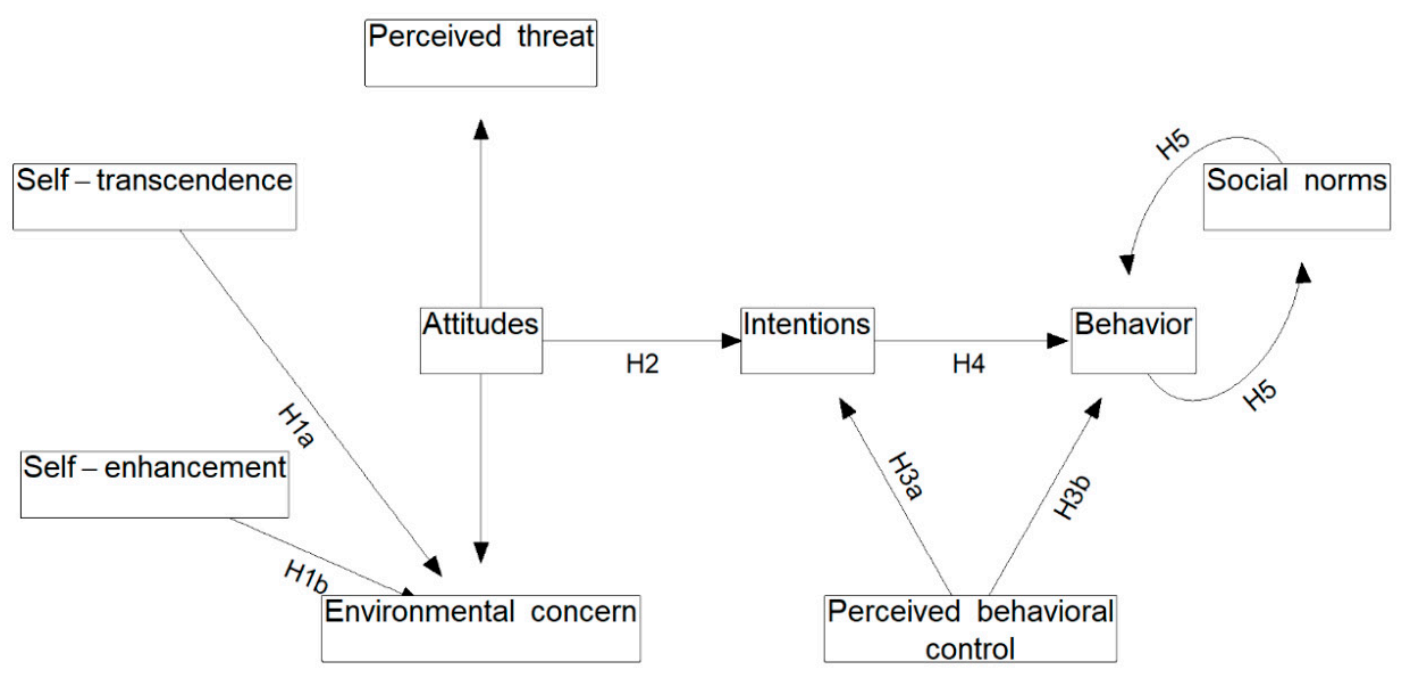

Figure 1. Conceptual framework used in the present study.

\subsection{Values and Attitude}

In essence, values are responses to three universal human requirements: What is needed by the individual as a biological organism, to ensure the continuation and uninterrupted operation of groups and for social interaction to be coordinated. Their unique features, such as relative stability in time and universality $[30,31]$, have seen several authors apply them in studies related to organic food consumption $[23,29,32]$. Due to their abstract nature, values affect behaviors indirectly through some mediating concepts, such as attitudes [22,23]. A value-attitude-behavior relationship has been identified in several organic food contexts [33-35]. The number of studies applying the theory of basic human values $[25,31]$ has reported that self-transcendence values (universalism and benevolence) are significant factors in consumers' organic food purchase decisions [5,35-37]. In contrast, consumers who cherish self-enhancement values (achievement, power, hedonism) are most unlikely to favor any organic options [22,38,39]. In our model, we anticipate the two value clusters to differently affect attitudes because they contrast each other by emphasizing concern for the welfare of others against emphasizing success and dominance over others [25]. Based on this, we hypothesize:

Hypothesis 1a (H1a). Self-transcendence values have a positive and significant effect on environmental concern.

Hypothesis 1b (H1b). Self-enhancement values have a negative and significant effect on environmental concern.

Even though values can guide behavior and explain the most abstract motivations of individuals, research is clear that there are more direct antecedents of behavior, such as attitudes and intentions $[40,41]$. In this sense, we propose that the organic food purchasing model must include some kind of an attitudinal construct.

\subsection{Attitude and Behavioral Intention}

There is a general agreement that attitudes can be defined as the degree to which a person favorably or unfavorably evaluates a specific object [42]. According to Oreg and Katz-Gerro, attitudes involve beliefs about the consequences of behavior (environmental concerns) and how these are assessed (perceived threats) [43]. The theory of planned behavior states that attitudes are a key factor in shaping behavioral intentions, whereby more favorable attitudes lead to a stronger intention to perform the behavior [44]. Similarly, various studies on organic food consumption demonstrate a positive and significant relationship between consumers' attitudes and their purchase intentions $[9,45,46]$. Thus, the following hypothesis can be derived: 
Hypothesis 2 (H2). Attitude has a positive and significant effect on organic food purchase intentions.

\subsection{Perceived Behavioral Control, Behavioral Intention, and Behavior}

The concept of perceived behavioral control (PBC) was introduced by Ajzen [42]. PBC can have a direct effect on behavior, and it can also influence behavior indirectly by its impact on intentions. It is similar to, and also partly derives from, the concept of self-efficacy [47], according to which the individual's motivation for behavior depends on expectations regarding their own efficiency.

According to the PBC concept, when intending to perform a specific behavior, an individual will assess his self-control against different factors that might feel out of its control [10,48]. While earlier research conceptualized PBC as influenced by external barriers, including price and availability [49], they ignored the roles of consumers' internal factors [9]. PBC is based on individuals' beliefs about their influence over the situation [42] and the internal factors that facilitate their behavior. The behavioral intentions and the actual behavior depend on the perceived ease or difficulty of performing it. When individuals believe that they have more resources and opportunities and expect fewer obstacles (e.g., price, availability, trust, labeling, lack of information), their PBC will be stronger, and their purchase intentions will be greater. If $\mathrm{PBC}$ is low, the purchase intentions will remain low as well, despite other behavioral antecedents [50,51]. While it is evident nowadays that consumers hold generally positive attitudes towards organic food products, barriers related to PBC continue to negatively affect consumption behavior [46,50,52].

Consistent with several other previous studies [9-11,50,53,54], we postulate the following hypotheses:

Hypothesis 3a (H3a). PBC has a positive and significant effect on behavioral intention.

Hypothesis $3 \mathbf{b}(\mathbf{H} 3 \mathbf{b})$. PBC has a positive and significant effect on behavior.

\subsection{Behavioral Intention and Behavior}

Behavioral intentions were defined by Fishbein et al. as the agent's subjective probability that he or she will perform the behavior [55]. However, this definition was later criticized by Warshaw et al. [56], who defined behavioral intention as the degree to which a person has formulated conscious plans to perform or not perform some specified future behavior. In his later work, Ajzen interpreted the concept of behavioral expectation as an indicator of how hard people are willing to try and how much of an effort they are planning to exert $[42,57,58]$. In the organic food context, behavioral intentions are associated with positive word-of-mouth recommendations, a commitment to repurchase organic food items and a commitment to pay price premiums [9].

However, the intention to behave and the actual behavior arising from that intention are conceptually distinct. While many studies have argued that intentions do not necessarily predict subsequent behavior [9,59-61], behavioral intentions are a widely recognized antecedent of behavior $[42,43,46,62,63]$. Therefore, we propose the following hypothesis:

Hypothesis 4 (H4). Behavioral intention has a positive and significant effect on behavior.

\subsection{Social Norms and the Social Feedback Loop}

While personal norms relate to the feeling of morality in an individual's mind to act in a certain way [46], social norms describe the perceived social influence on an individual to engage or not engage in environmentally friendly purchasing [64]. Prior research suggests that social norms have a positive effect on organic purchasing behavior. For example, Golob et al. [15], who investigate the impact of environmentally conscious purchase behavior and green skepticism on organic food consumption, demonstrate that social norms have a significant effect on behavior and intentions. 
Du et al. [65] obtain a similar conclusion in a model where they explore organic consumption behavior from a social identification perspective. In addition, Sandhu et al. [66] show that social norms, among other determinants, significantly influence personal norms towards organic food. Social norms are, in general, expected to positively influence organic consumption because individuals adhere to social pressure from referents (e.g., family, friends, and colleagues) that provide insights into what behavior is acceptable and appropriate [67]. Consumers are likely to have access to information on appropriate behavior through interactions with referents from their social circle.

An important property of social norms is that they induce a feedback loop: Consumers create behaviors, but at the same time are the creation of social systems [16]. While social feedback loops have been examined in other research areas, such as in the dynamics of a human-ecosystem [68], religious systems [69], and absenteeism [70], this feature has been ignored in the domain of organic food purchasing until now. Recognized as an important mechanism that enables an individual to alter and construct new behaviors [16], we hypothesize the following:

Hypothesis 5 (H5). Social norms induce a positive feedback loop between individual and group behavior.

\section{Data and Methods}

\subsection{Data}

This study is based on individual-level data obtained from two international surveys: The International Social Survey Program Environmental module (ISSP) [71], and the European Social Survey Wave 5 (ESS) [72], relating to 2010 as the latest publication year. The ESS database provided 11 questions to measure five of Schwartz's values (universalism, benevolence, achievement, power, hedonism), composing two bipolar dimensions (self-transcendence, self-enhancement). According to past studies, these two value types seem to be the most important and meaningful for environmental attitudes. All other variables, i.e., attitudes, intentions, perceived behavioral control, and organic food purchasing, come from the ISSP database. Altogether, 14,009 individuals were included in the matched database covering 15 European countries, Russia, and Israel.

To integrate Schwartz's value types from ESS into the model for organic food purchasing, the ISSP and ESS databases were combined using the "nearest neighbor distance hot deck method" from StatMatch [73], with statistical matching based on country, gender, year of birth, years of schooling (EDUY), and level of agreement with the statement "modern science enables solving environmental problems" (SCI). The two surveys do not overlap with regard to other measured constructs. The statistical matching, accomplished with the StatMatch package [74], is described in more detail in the next subsection.

An integrated conceptual model composed of the vital psychosocial antecedents of organic food purchasing behavior was developed and tested with structural equation models in the R program [75]. Structural equation modelling (SEM) allowed us to test a measurement model and a structural model simultaneously.

The structural model was estimated with lavaan [76], charts were created with ggplot2 [77] and ggraph [78] packages, spatial lag models were estimated with the spdep package [79,80], and dplyr [81] was used for basic data manipulation.

\subsection{Statistical Matching}

As the data needed to build the model for organic food purchasing do not exist in one data set, we used 22 items from two databases-the ISSP and the ESS, which were combined with the use of statistical matching. This technique is useful when we have two databases with a set of common variables (e.g., $\mathrm{X}$; in our case these were demographic variables: age, gender, years of schooling, country) and two sets of variables that each appear in only one data set (e.g., $Y$ appears only in the first one, while $\mathrm{Z}$ appears only in the second one). As we are (among other things) interested in the 
relationship between $\mathrm{Y}$ and $\mathrm{Z}$, it is our objective to gain information about the joint distribution of $X, Y$, and $Z$. Using assumptions on the distribution of these variables [82], we can use the statistical matching function that finds a donor record in one data set for each record in the second one. In our case, the ISSP and ESS databases were combined using the "nearest neighbor distance hot deck method" from StatMatch [73]. This means that each record in the recipient file (ISSP) was matched with the closest record in the donor file (ESS), according to a distance measure (we used the Manhattan metric) computed using the matching variables $\mathrm{X}$. The result was a synthetic data set with all the variables of our interest. Figure 2 illustrates this situation.

\begin{tabular}{|lll|llll|}
\hline ISSP & \multicolumn{11}{|l|}{} & \\
\hline $\mathbf{Y}_{1}$ & $\cdots$ & $\mathbf{Y}_{\mathbf{L}}$ & $\mathbf{X}_{\mathbf{l}}$ & $\ldots$ & $\mathbf{X}_{\mathbf{M}}$ \\
\hline
\end{tabular}

\begin{tabular}{|lll|llll|}
\hline ESS & \multicolumn{11}{|l|}{} \\
\hline $\mathbf{X}_{\mathbf{l}}$ & $\cdots$ & $\mathbf{X}_{\mathbf{M}}$ & $\mathbf{Z}_{\mathbf{l}}$ & $\cdots$ & $\mathbf{Z}_{\mathbf{N}}$ \\
\hline
\end{tabular}

\begin{tabular}{|lll|llll|llll|}
\hline \multicolumn{11}{|l|}{ Synthetic (matched) dataset } \\
\hline $\mathbf{Y}_{\mathbf{1}}$ & $\ldots$ & $\mathbf{Y}_{\mathbf{L}}$ & $\mathbf{X}_{\mathbf{1}}$ & $\ldots$ & $\mathbf{X}_{\mathbf{M}}$ & $\mathbf{Z}_{\mathbf{1}}$ & $\ldots$ & $\mathbf{Z}_{\mathbf{N}}$ \\
\hline
\end{tabular}

Figure 2. Graphical representation of the statistical matching.

The mean, variance, and correlations between variables of the synthetic data set have similar properties to the ESS data set concerning questions regarding values, as shown in Table 1 and Figure 3.

All predictors of organic food purchasing, except for the Schwartz values, were rescaled to the $[0,1]$ range, where 0 indicates the minimum and 1 the maximum of the underlying Likert scale to aid interpretation.

Attitudes consisted of two items measuring environmental concern and two items measuring perceived threat. Behavioral intentions, a mediator between attitudes and organic food purchasing, was measured with three items. Next, the purchasing organic food variable related to buying fruit and vegetables without pesticides and chemicals. The construct of perceived behavioral control consisted of two questions that reflect an individual's assessment of their self-efficacy and controllability of behavior. Finally, the model included the direct influence of social norms on organic food purchasing by establishing a feedback loop between behavior of the individual and that of others. A detailed description of individual model items, together with descriptive statistics, is presented in Table 2. Since some data were missing in the ISSP data set, we excluded incomplete observations, leaving us with a final sample size of 14,009 observations. The omission of incomplete records did not distort the descriptive statistics of the observed variables.

Table 1. Comparison of mean values between original and synthetic data sets.

\begin{tabular}{lcccc}
\hline \multirow{2}{*}{\multicolumn{1}{c}{ Variable }} & \multicolumn{2}{c}{ ESS } & \multicolumn{2}{c}{ Synthetic } \\
\cline { 2 - 5 } & Mean & St.dev & Mean & St.dev. \\
\hline Important that people are treated equally and have equal opportunities (IPEQOPT) & 4.956 & 1.037 & 4.992 & 1.02 \\
Important to understand different people (IPUDRST) & 4.576 & 1.088 & 4.603 & 1.082 \\
Important to care for nature and environment (IMPENV) & 4.865 & 1.043 & 4.872 & 1.025 \\
Important to help people and care for others' well-being (IPHLPPL) & 4.814 & 0.998 & 4.813 & 1.002 \\
Important to be loyal to friends and be devoted to people who are close (IPLYLFR) & 5.054 & 0.925 & 5.087 & 0.891 \\
Important to show abilities and be admired (IPSHABT) & 3.92 & 1.378 & 3.73 & 1.405 \\
Important to be successful and that people recognize achievements (IPSUCES) & 3.921 & 1.35 & 3.721 & 1.382 \\
Important to be rich, have money and expensive things (IMPRICH) & 3.055 & 1.362 & 2.894 & 1.322 \\
Important to get respect from others (IPRSPOT) & 3.961 & 1.356 & 3.796 & 1.393 \\
Important to have a good time (IPGDTIM) & 4.007 & 1.363 & 4.121 & 1.324 \\
Important to seek fun and things that give pleasure (IMPFUN) & 3.913 & 1.392 & 3.848 & 1.353 \\
\hline
\end{tabular}


Table 2. Descriptive statistics.

\begin{tabular}{|c|c|c|c|c|c|c|c|c|}
\hline Construct/Label & Items & Source & Reference & $\mathbf{N}$ & Mean & St. dev. & Min & $\operatorname{Max}$ \\
\hline \multirow{5}{*}{$\begin{array}{l}\text { Self-transcendence } \\
\quad(5 \text { items })\end{array}$} & Important that people are treated equally and have equal opportunities (IPEQOPT) & ESS & \multirow{5}{*}{ [83] } & 14,009 & 4.995 & 1.013 & 1 & 6 \\
\hline & Important to understand different people (IPUDRST) & ESS & & 14,009 & 4.611 & 1.075 & 1 & 6 \\
\hline & Important to care for nature and environment (IMPENV) & ESS & & 14,009 & 4.871 & 1.026 & 1 & 6 \\
\hline & Important to help people and care for others' well-being (IPHLPPL) & ESS & & 14,009 & 4.823 & 0.988 & 1 & 6 \\
\hline & Important to be loyal to friends and be devoted to people who are close (IPLYLFR) & ESS & & 14,009 & 5.101 & 0.876 & 1 & 6 \\
\hline \multirow{6}{*}{$\begin{array}{l}\text { Self-enhancement } \\
\text { (6 items) }\end{array}$} & Important to show abilities and be admired (IPSHABT) & ESS & \multirow{6}{*}{ [83] } & 14,009 & 3.711 & 1.401 & 1 & 6 \\
\hline & Important to be successful and that people recognize achievements (IPSUCES) & ESS & & 14,009 & 3.72 & 1.384 & 1 & 6 \\
\hline & Important to be rich, have money and expensive things (IMPRICH) & ESS & & 14,009 & 2.876 & 1.305 & 1 & 6 \\
\hline & Important to get respect from others (IPRSPOT) & ESS & & 14,009 & 3.788 & 1.394 & 1 & 6 \\
\hline & Important to have a good time (IPGDTIM) & ESS & & 14,009 & 4.159 & 1.308 & 1 & 6 \\
\hline & Important to seek fun and things that give pleasure (IMPFUN) & ESS & & 14,009 & 3.876 & 1.33 & 1 & 6 \\
\hline \multirow{2}{*}{$\begin{array}{c}\text { Environmental concern } \\
\text { (2 items) }\end{array}$} & Worry about future environment $(\mathrm{Q} 10 \mathrm{a})$ & ISSP & \multirow{2}{*}{ [83] } & 14,009 & 0.511 & 0.286 & 0 & 1 \\
\hline & Worry: progress harming the environment (Q10c) & ISSP & & 14,009 & 0.545 & 0.262 & 0 & 1 \\
\hline Perceived threat & How dangerous for the environment-pesticides and chemicals used in farming (Q14c) & ISSP & Two items were taken from & 14,009 & 0.726 & 0.22 & 0 & 1 \\
\hline (2 items) & How dangerous for the environment-modifying the genes of certain crops (Q14f) & ISSP & [83] & 14,009 & 0.626 & 0.267 & 0 & 1 \\
\hline \multirow{2}{*}{$\begin{array}{l}\text { Perceived behavioral control } \\
\text { ( } 2 \text { items })\end{array}$} & To do about the environment: too difficult (Q13a) & ISSP & \multirow[b]{2}{*}{ [83] } & 14,009 & 0.569 & 0.287 & 0 & 1 \\
\hline & No point unless others do the same (Q13d) & ISSP & & 14,009 & 0.568 & 0.299 & 0 & 1 \\
\hline \multirow{3}{*}{$\begin{array}{l}\text { Behavioral intentions } \\
\quad(3 \text { items })\end{array}$} & Protect the environment: pay much higher prices (Q12a) & ISSP & \multirow{3}{*}{$\begin{array}{l}\text { Three non-specific items } \\
\text { were taken from [83] }\end{array}$} & 14,009 & 0.439 & 0.283 & 0 & 1 \\
\hline & Protect the environment: pay much higher taxes (Q12b) & ISSP & & 14,009 & 0.362 & 0.284 & 0 & 1 \\
\hline & Protect the environment: cut your standard of living (Q12c) & ISSP & & 14,009 & 0.451 & 0.287 & 0 & 1 \\
\hline $\begin{array}{c}\text { Green purchasing } \\
(\text { () }\end{array}$ & Buying fruit and vegetables without pesticides or chemicals (Q20b) & ISSP & & 14,009 & 0.424 & 0.319 & 0 & 1 \\
\hline $\begin{array}{c}\text { Social norms } \\
()\end{array}$ & Spatial lag in green purchasing (WQ20b) & ISSP & & 14,009 & 0.418 & 0.128 & 0 & 1 \\
\hline
\end{tabular}

Note. Statistical units are individuals. 
ESS

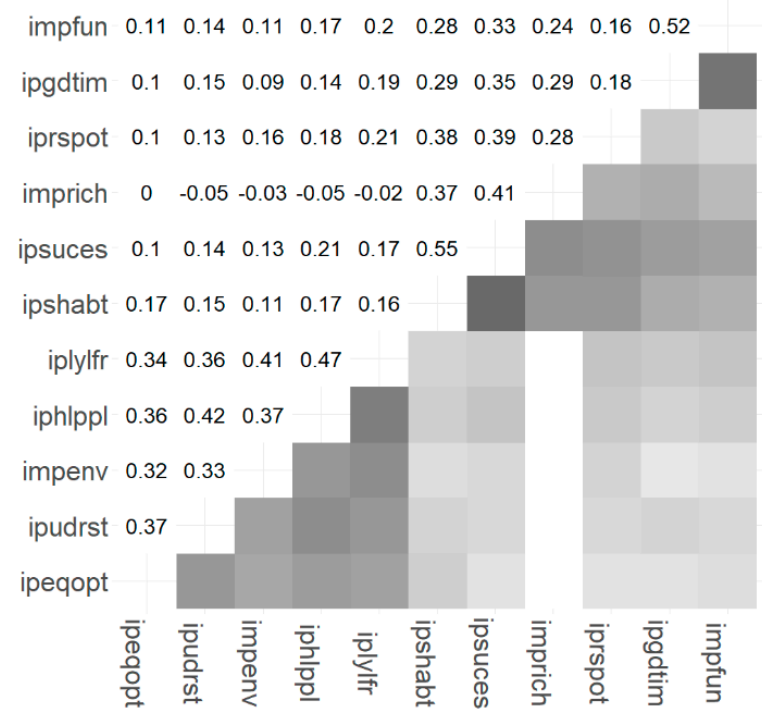

Synthetic

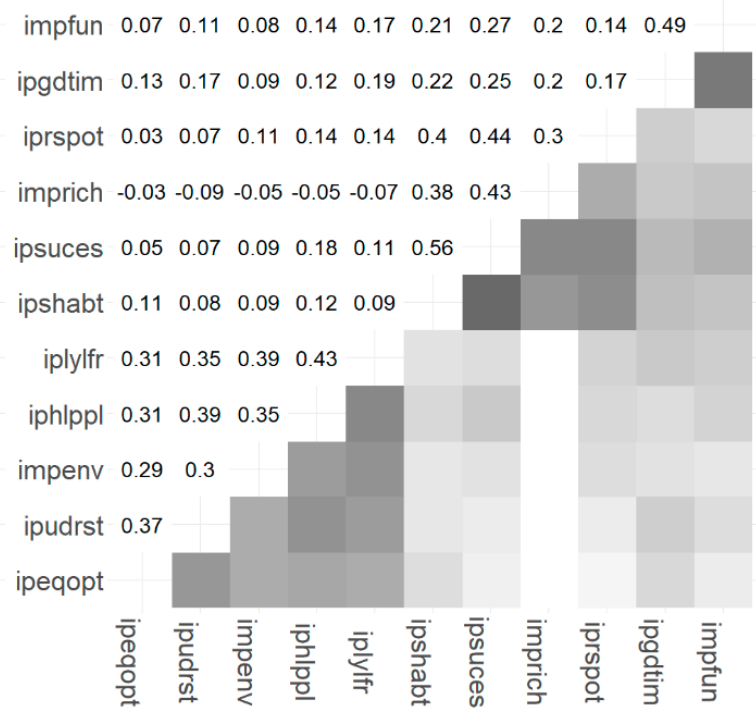

Figure 3. Correlation within the original and synthetic data sets.

\subsection{Feedback Loop}

To estimate the feedback loop, we use a spatial lag model where a spatial connectivity matrix was defined via a dissimilarity index between pairs of observations (Equation (1)):

$$
W_{i j}=\left\{\begin{array}{lr}
s q r t(1-\text { dissimilarity }), & \text { if dissimilarity } \leq \\
0, & 0.05 \\
\text { else }
\end{array}\right.
$$

where $W$ is a connectivity matrix, dissimilarity is defined by a Gower distance function [84] between "Years in school", "gender", and, "age" for each individual to form a dissimilarity matrix. Diagonal elements of the matrix were set to 0 since a person cannot be a neighbor of oneself, and the matrix was row-standardized (the sum of row weights equals 1). Persons with a similar age and years of schooling have a higher weight than those who are more "distant", while after a certain cut-off the weights equal zero.

In this definition of neighborhood, two persons are said to be neighbors if they reside in the same country and have a similar age and years of schooling. A social norm is defined as average behavior weighted by the inverse distance.

The correlation of social norms and behavior, measured by "How often does someone make a special effort to buy fruit and vegetables grown without pesticides or chemicals", is displayed in Figure 4. Persons whose neighborhood "sometimes" makes an effort are more likely to "never" make a special effort compared to people whose proximity "often" makes a special effort.

The behavior-social norms correlation points to the presence of mutual dependence, which provides a basis for the feedback loop. Simultaneous feedback is a feature of the spatial regression models that arise from spatial dependence relying on a spatial connectivity matrix definition of neighborhood.

The positive Pearson correlation coefficient indicates a presence of mutual dependence, meaning that individuals behave similarly to their peers-the social norm. Those who are surrounded by people that often make a spatial effort to buy fruit and vegetables grown without pesticides or chemicals are more likely also to make a special effort. On the other hand, those who are surrounded by people that less often make a special effort are less likely to make a special effort themselves. In the next section, we formally test the magnitude of the effect that each person has on the behavior of others and the reinforcing feedback that further intensifies the decision. 


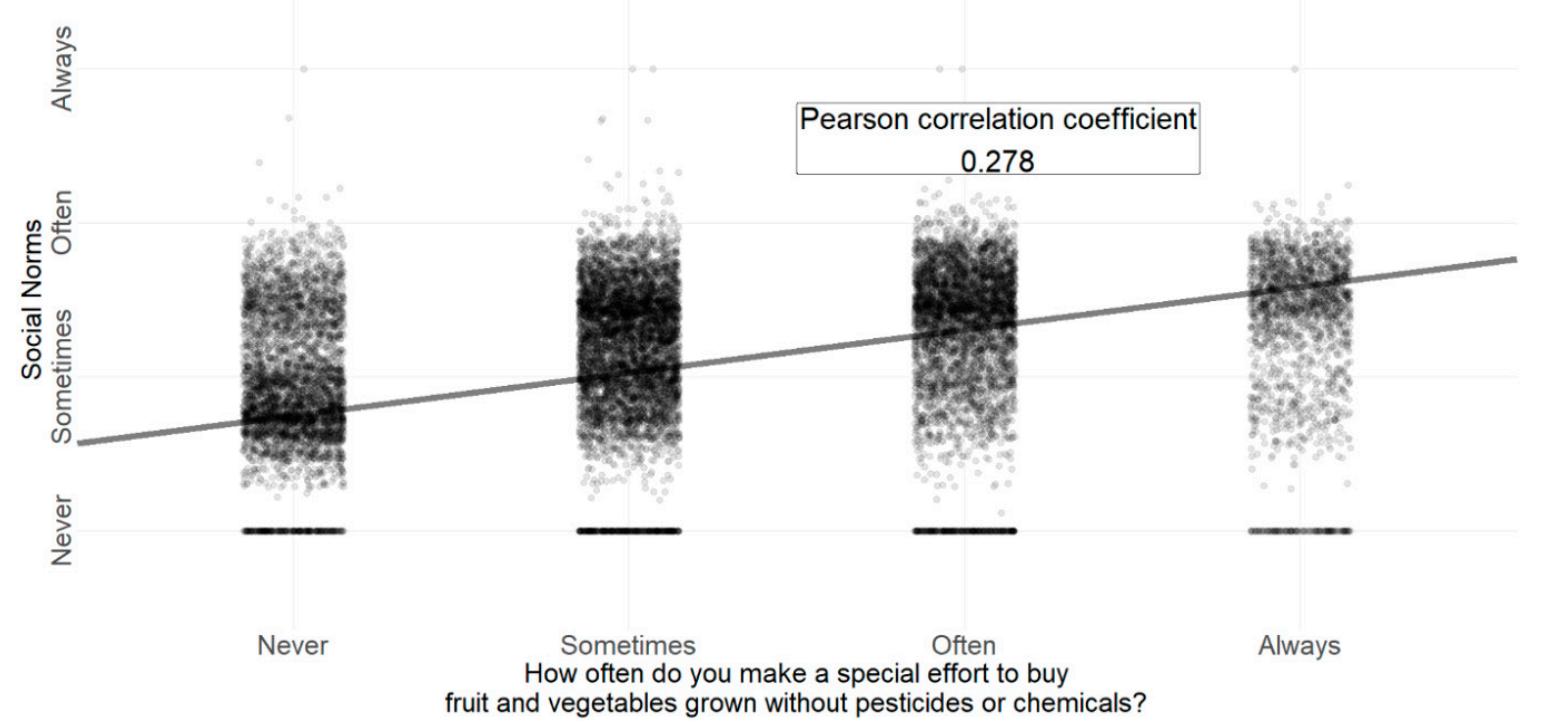

Figure 4. Correlation of individual behavior and social norms.

\section{Results}

\subsection{Measurement Model Analysis}

Confirmatory factor analysis (CFA) was conducted before the structural model was examined (Table 3) in line with Marcoulides and Schumacker's criteria for model fit [85], with the CFA results indicating a satisfactory model fit.

Table 3. Structural results of model fit.

\begin{tabular}{lcc}
\hline \multicolumn{1}{c}{ Indicator } & SEM & CFA \\
\hline Goodness of Fit Index (GFI) & 0.951 & 0.956 \\
GFI Adjusted for Degrees of Freedom (AGFI) & 0.936 & 0.942 \\
Root Mean Square Residual (RMR) & 0.053 & 0.060 \\
Chi-Square & 8067 & 6726 \\
Chi-Square DF & 195.0 & 158.0 \\
RMSEA Estimate & 0.054 & 0.053 \\
Bentler's (1990) Comparative Fit Index (CFI) & 0.886 & 0.906 \\
Bentler and Bonett's (1980) Non-normed Index (NNFI) & 0.865 & 0.886 \\
Bentler and Bonett's (1980) Normed Fit Index (NFI) & 0.883 & 0.904 \\
\hline
\end{tabular}

To test for convergent validity [86], we assessed whether each observed variable's estimated maximum likelihood factor loading on its latent construct is significant (Table 3). We may confirm the study has convergent validity because all factor loadings were significant. Finally, internal reliability indicated by Cronbach's alpha for each construct was higher than or close to 0.6. Although the agreed upon limit for Cronbach alpha coefficient is 0.7 [87], a coefficient close to 0.6 generally will be accepted in social science research where unstable psychosocial constructs are composed of a small number of variables (Table 4) [88,89]. 
Table 4. Standardized loadings of indicators and convergent validity.

\begin{tabular}{|c|c|c|}
\hline $\begin{array}{c}\text { Construct } \\
\text { (Cronbach's alpha) }\end{array}$ & Variable & Loading \\
\hline \multirow{5}{*}{$\begin{array}{l}\text { Self-transcendence } \\
\qquad(0.725)\end{array}$} & $\begin{array}{l}\text { Important that people are treated equally and have } \\
\text { equal opportunities (IPEQOPT) }\end{array}$ & $0.515^{* * *}$ \\
\hline & Important to understand different people (IPUDRST) & $0.594^{* * *}$ \\
\hline & $\begin{array}{l}\text { Important to care for nature and environment } \\
\text { (IMPENV) }\end{array}$ & $0.536^{* * *}$ \\
\hline & $\begin{array}{l}\text { Important to help people and care for others' } \\
\text { well-being (IPHLPPL) }\end{array}$ & $0.651 * * *$ \\
\hline & $\begin{array}{l}\text { Important to be loyal to friends and be devoted to } \\
\text { people who are close (IPLYLFR) }\end{array}$ & $0.649^{* * *}$ \\
\hline \multirow{6}{*}{$\begin{array}{l}\text { Self-enhancement } \\
\qquad(0.735)\end{array}$} & $\begin{array}{l}\text { Important to show abilities and be admired } \\
\text { (IPSHABT) }\end{array}$ & $0.701 * * *$ \\
\hline & $\begin{array}{l}\text { Important to be successful and that people recognize } \\
\text { achievements (IPSUCES) }\end{array}$ & $0.774^{* * *}$ \\
\hline & $\begin{array}{c}\text { Important to be rich, have money and expensive } \\
\text { things (IMPRICH) }\end{array}$ & $0.543^{* * *}$ \\
\hline & Important to get respect from others (IPRSPOT) & $0.554^{* * *}$ \\
\hline & Important to have a good time (IPGDTIM) & $0.395^{* * *}$ \\
\hline & $\begin{array}{l}\text { Important to seek fun and things that give pleasure } \\
\text { (IMPFUN) }\end{array}$ & $0.379 * * *$ \\
\hline \multirow{2}{*}{$\begin{array}{l}\text { Environmental concern } \\
\qquad(0.561)\end{array}$} & Worry about future environment (Q10a) & $0.707^{* * *}$ \\
\hline & Worry: progress harming the environment (Q10c) & $0.548^{* * *}$ \\
\hline \multirow{2}{*}{$\begin{array}{l}\text { Perceived threat } \\
\qquad(0.614)\end{array}$} & $\begin{array}{l}\text { How dangerous for the environment-pesticides and } \\
\text { chemicals used in farming (Q14c) }\end{array}$ & $0.886^{* * *}$ \\
\hline & $\begin{array}{l}\text { How dangerous for the environment-modifying the } \\
\text { genes of certain crops (Q14f) }\end{array}$ & $0.509 * * *$ \\
\hline \multirow{3}{*}{$\begin{array}{l}\text { Intentions } \\
\quad(0.849)\end{array}$} & $\begin{array}{l}\text { Protect the environment: pay much higher prices } \\
\text { (Q12a) }\end{array}$ & $0.877^{* * *}$ \\
\hline & $\begin{array}{l}\text { Protect the environment: pay much higher taxes } \\
\qquad(\mathrm{Q} 12 \mathrm{~b})\end{array}$ & $0.842 * * *$ \\
\hline & $\begin{array}{l}\text { Protect the environment: cut your standard of living } \\
\text { (Q12c) }\end{array}$ & $0.712 * * *$ \\
\hline \multirow{2}{*}{$\begin{array}{l}\text { Perceived behavioral control } \\
\qquad(0.579)\end{array}$} & To do about the environment: too difficult (Q13a) & $0.653^{* * *}$ \\
\hline & No point unless others do the same (Q13d) & $0.615^{* * *}$ \\
\hline
\end{tabular}

Note. Cronbach's alpha in parenthesis. ${ }^{* * *} p<0.001$,

\subsection{Structural Model Analysis}

Hu and Bentler [90] argued that SRMR lower than the threshold of 0.08 and RMSEA lower than 0.06 indicate a good fit between the hypothesized model and the observed data. Our model exhibited SRMR and RMSEA values of 0.054 and 0.053 , respectively. Moreover, the goodness of fit index (GFI) and index adjusted for degrees of freedom (AGFI) with values of 0.951 and 0.936 were both above the generally acceptable level (0.90). Other indices, with the following values: 0.886 (CFI), 0.865 (NNFI) and 0.883 (NFI), also indicated an acceptable model fit (Table 3).

The results of the structural model (Table 5, Figure 5) show that almost all relationships in the model for the organic food purchase decision-making process were positive and statistically significant and had a positive sign. The only exception was the self-enhancement value with no effect on the environmental concern construct. Self-transcendence was positively associated with environmental 
concern and explained a significant share of variation in the environmental concern. Attitudes were positively associated with intentions and, together with perceived behavioral control, positively influenced behavior with a positive feedback loop. Specifically, results show that:

- H1a. Self-transcendence values have a positive and significant effect on environmental concern,

- H1b. Self-enhancement values do not influence environmental concern,

- H2. Attitude has a positive and significant effect on organic food purchase intentions,

- H3a. PBC has a positive and significant effect on behavioral intention,

- H3b. PBC has a positive and significant effect on behavior,

- H4. Behavioral intention has a positive and significant effect on behavior,

- H5. Social norms induce a positive feedback loop between individual and group behavior.

Table 5. Regression coefficients of the structural model.

\begin{tabular}{cccc}
\hline Regression & Explanatory Variable & Estimate & Std. Error \\
\hline \multirow{2}{*}{ Environmental concern } & Self-transcendence & $0.069^{* * *}$ & 0.017 \\
& Self-enhancement & 0.003 & 0.006 \\
\hline \multirow{2}{*}{ Intentions } & Attitudes & $0.438^{* * *}$ & 0.107 \\
& Perceived behavioral control & $0.190^{* *}$ & 0.077 \\
\hline \multirow{2}{*}{ Behavior } & Intentions & $0.176^{* * *}$ & 0.015 \\
& Perceived behavioral control & $0.219^{* * *}$ & 0.025 \\
\hline Social norms & Social norms & $0.262^{* *}$ & 0.108 \\
\hline
\end{tabular}

Note. ${ }^{* * *} p<0.001,{ }^{* *} p<0.01$; standard errors in parenthesis.

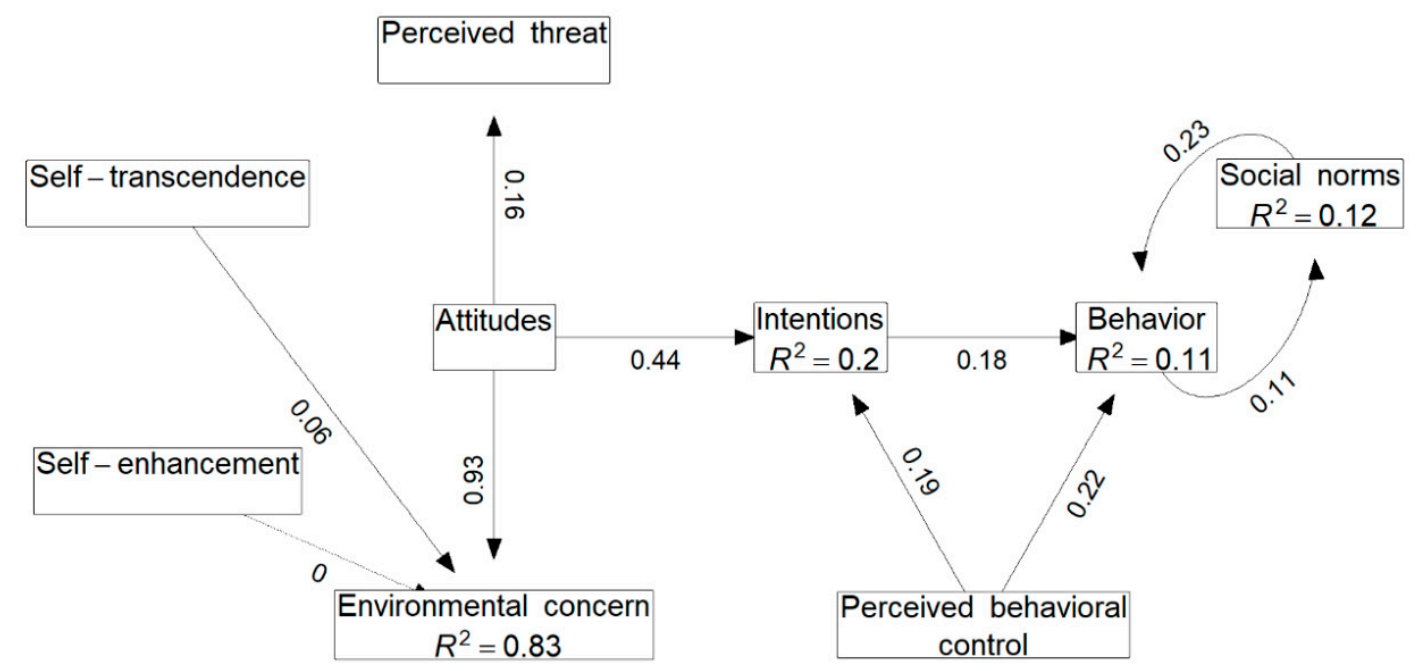

Figure 5. Results.

\subsection{Results by Country}

After estimating the full structural model, we tested the feedback loop hypothesis on a partial spatial lag model for each country separately. Below, we only report the spatial coefficient estimates by country. The spatial lag coefficient (Figure 6), which, on average, was 0.23 , varied between countries. The weighted average value of the country-specific spatial lag coefficient met our expectations of the full structural model fitted with a maximum likelihood estimation with robust "Huber-White" standard errors.

Individuals in countries with higher estimated spatial lag coefficients have more power to influence the behavior of their peers. This means that a change in an individual's behavior is followed by a 
change in behavior of others, which reinforces the initial variation of behavior-positive feedback loop. The positive feedback loop is most pronounced in Norway and Slovenia, while not confirmed in Israel, Russia, Lithuania, and Slovakia.

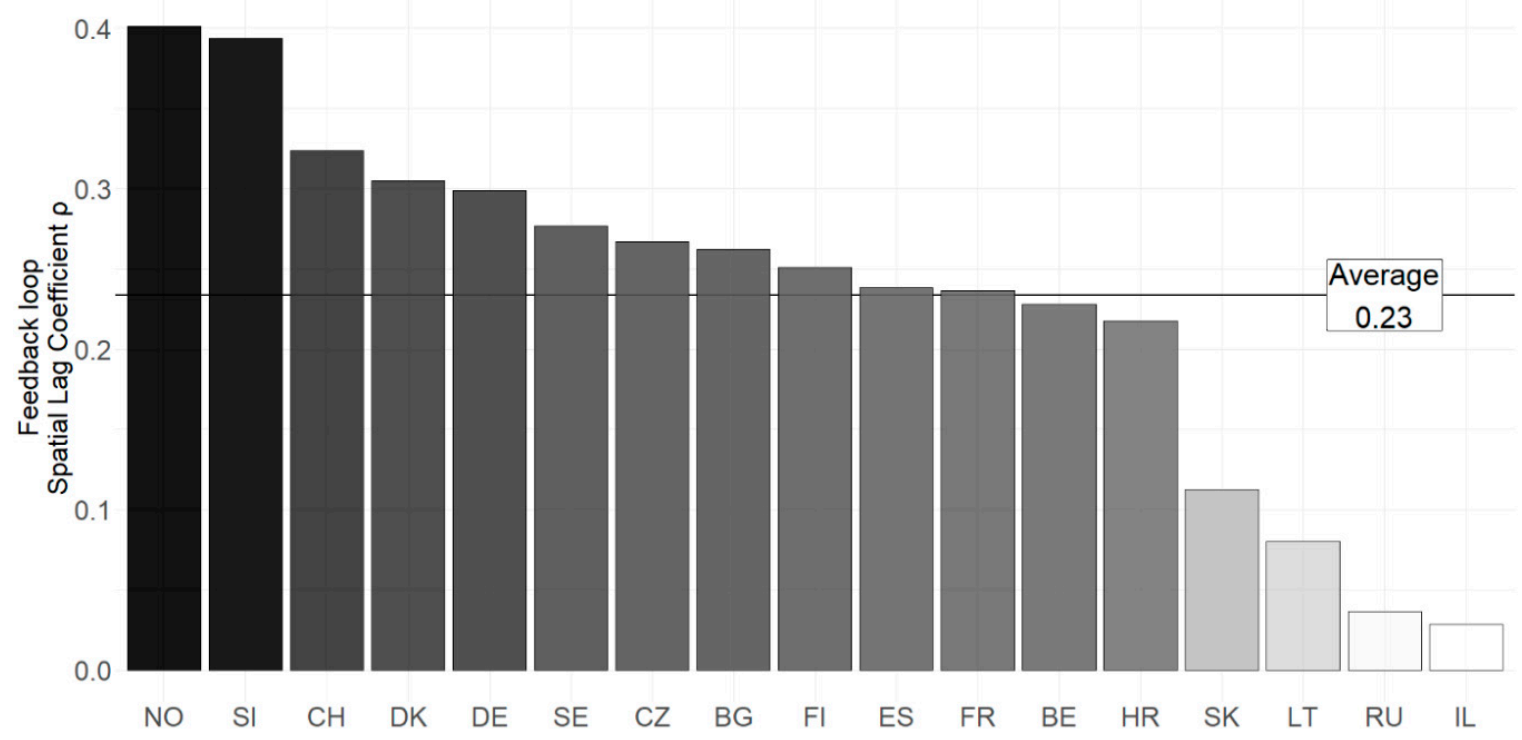

Figure 6. Spatial lag coefficient $\rho$ by country.

\section{Discussion and Limitations}

Bringing about a change in consumption patterns is a complex process that involves various important factors and calls for a holistic approach that seeks to understand what drives people to purchase food labeled organic. To address the deficit in what is currently known about the factors influencing organic purchasing, we have developed and tested a structural model that links customers' values according to Schwartz's typology of human values with important attitudinal and behavioral concepts from past research. Modifying the existing psychosocial framework with a component that stresses the importance of reciprocity between individual behavior and social norms that intensifies future actions has shown to be an essential determinant of the organic food decision-making process. Positive feedback enables an initial change in consumer behavior to buy organic food to be magnified as that change resounds through social norms. This finding is of great importance, as it demonstrates that a change in behavior of just one person affects not only him but also others, which exponentially increases the effect on the society.

Methodologically, this study utilizes two valuable techniques that enable a simplified reflection of the actual psychosocial decision-making process using a large sample. Statistical matching is extremely useful for taking advantage of existing data sources as an alternative to conducting new surveys. Moreover, a spatial lag was introduced to estimate the value of the social norm concept. The combined methodological approach used helped to show that, apart from the importance of the self-transcendence values and feedback loop in the newly developed structural model, it is individuals' attitudes that affect purchase intention, which, together with perceived behavioral control, lead to organic food buying. Our findings are consistent with existing studies that examine a value-attitudebehavior relationship in organic purchasing [33-35] as well as those exploring the effect of social norms on consumer behavior $[15,66]$. The study's original contribution to the theory pertains to the inclusion of the social feedback loop in the domain of organic food, where we show that a model that lacks the two-way interaction and accompanying compounding effect of social norms and individual behavior is likely to underestimate the proposed relationships and forecasts for a greener future in specific countries. 
The critical finding of the examined reciprocity between individual behavior and social norms is that it can serve as leverage when the desired outcome of an effort to change an individual's behavior is multiplied via the feedback loop. This is especially pronounced in Norway and Slovenia where marketers can make more cost- and time-efficient use of persuasive messages and requests through a robust feedback loop that reinforces future actions. By using influencer marketing to strengthen brand recognition and engagement, the relationship could be even more powerful.

Although one can reasonably assume that the examined feedback loop may have a greater influence on the average individual in a collectivist society, our results suggest the opposite. The results of the current study (Figure 6) show that individualistic nations appear highest on the feedback loop ranking [26], except for Slovenia with its unique historical brand of self-management socialism, whose inhabitants generally attribute their interest and activity to their achievement, success, independence, enjoyment, prestige, and seek a more individual trajectory in the society to make a unique personal contribution to society. While the individuals in these countries might not actively promote the welfare of others, they can still score highly for avoiding actions that can potentially harm others [91].

Policymakers and marketing specialists know that altering the interests of individuals is central to making any progress in changing their behavior. Two common strategies are used to motivate the adoption of sustainable practices and consumption: Ones that inform and educate people and those which influence supply and demand in a particular product category. While existing policy measures and marketing actions in the developed world generally modify the food market via these two broad categories, including widespread nutrition education in schools and fiscal measures, another relevant approach to promoting organic food consumption includes psychosocial instruments targeting individuals who share specific values and attitudes to sustainable consumption. As predicted, the self-transcendence values (universalism and benevolence) emerged as a significant indirect determinant of organic food purchasing behavior. Hence, individuals with high scores for self-transcendence might have greater awareness of threats to the environment than those under the influence of self-enhancement values. Such an individual is more likely to be attracted by the content relating to product safety and nutritional features. Since the values held by individuals do not change overnight, a systematic and strategic psychosocial-cultural-political-economic approach is clearly needed to support social transformation. In this context, our study shows the importance of policy and marketing campaigns to support specific cognitions and attitudes that trigger favorable actions, in our case organic food purchasing. Given that climate change is a fast-growing topic today, we expect that attitudes associated with green purchasing will strengthen even further. Accordingly, marketing specialists and policymakers can stimulate positive behavior by informing and educating people about their role in solving environmental problems by purchasing specific types of products over others.

In interpreting the results of this study, one should be aware of its limitations. Merging data sets can distort the results, which can be a reason why partial regression models exhibit low explanatory power. Another limitation concerns the measurement of social norms, where we use a dissimilarity index based on Gower's distance. The structure of the neighborhood (persons included in the social norms of each individual) is arbitrary and has not been extensively tested. Moreover, the study also faces the problem of relatively low factor loadings, in particular for variables in the self-enhancement value construct. Other drawbacks of the study concern the data. New ISSP and ESS surveys are expected to become available in 2020, yet the question about organic food purchasing has been omitted from the ISSP questionnaire. As a result, we were limited to using data from 2010. This raises the concern regarding the validity of our results due to the dynamic nature of the organic food market, which substantially expanded in the previous decade and amounted to 95 billion euros in 2018 [92]. We believe that the steep increase in the market is driven by the global rise in environmental concern that rose for six percentage points in the period from 2014 to 2019 [93], which results in an even stronger link between environmental concern, attitudes, and intentions. Therefore, an analysis on a newer data set would find even more support for our hypothesized model. Another issue relates to the 
cross-sectional nature of our data set. Although this limitation offers a pathway for future research, we argue that since values and social norms are both long-term concepts that only slowly change over time $[17,31]$, our model still provides robust evidence concerning the organic food purchasing process.

\section{Conclusions}

Much effort has been taken to study and understand what drives consumers to act sustainably. However, the dominant partial and fragmented existing research models and their inconclusive scientific evidence reduce certainty while creating marketing plans and developing policy measures. Although it is perplexing to study the behavior of individuals, characterized by unpredictability and instability, models should be as comprehensive as possible and reflect reality. We show that, in combination with other conceptually independent determinants, the focus on social norms and their two-way interaction with individual's behavior broaden and enhance our understanding of sustainable and organic consumption. Through a solid feedback loop that reinforces subsequent actions, we are building a more sustainable future than shown in existing studies.

Author Contributions: Conceptualization, M.O.; data curation, M.O.; formal analysis, M.O.; funding acquisition, K.P.; investigation, B.K. and N.M.; methodology, T.B.; project administration, K.P.; resources, M.D.; software, M.O.; supervision, K.P.; validation, T.B.; visualization, M.O.; writing—original draft, K.P.; writing—review and editing, R.S.-E. All authors have read and agreed to the published version of the manuscript.

Funding: This work received support from the Slovenian Ministry of Economic Development and Technology and the Slovenian Research Agency (Grant No. CRP-V5-1933) and the Slovenian Research Agency (Grant No. P5-009).

Conflicts of Interest: The authors declare no conflict of interest.

\section{References}

1. WHO Food Safety. Available online: https://www.who.int/news-room/fact-sheets/detail/food-safety (accessed on 18 May 2020).

2. FAO. Statistical Pocketbook 2018. World Food and Agriculture; FAO: Rome, Italy, 2018; ISBN 9789251088029.

3. Golob, U.; Kronegger, L. Environmental consciousness of European consumers: A segmentation-based study. J. Clean. Prod. 2019, 221, 1-9. [CrossRef]

4. Bai, L.; Wang, M.; Gong, S. Understanding the antecedents of organic food purchases: The important roles of beliefs, subjective norms, and identity expressiveness. Sustainability 2019, 11, 3045. [CrossRef]

5. Padilla Bravo, C.; Cordts, A.; Schulze, B.; Spiller, A. Assessing determinants of organic food consumption using data from the German National Nutrition Survey II. Food Qual. Prefer. 2013, 28, 60-70. [CrossRef]

6. Olson, E.L. The rationalization and persistence of organic food beliefs in the face of contrary evidence. J. Clean. Prod. 2017, 140, 1007-1013. [CrossRef]

7. Schäufele, I.; Hamm, U. Organic wine purchase behaviour in Germany: Exploring the attitude-behaviour-gap with data from a household panel. Food Qual. Prefer. 2018, 63, 1-11. [CrossRef]

8. Sarabia-Andreu, F.; Sarabia-Sánchez, F.J.; Parra-Meroño, M.C.; Moreno-Albaladejo, P. A multifaceted explanation of the predisposition to buy organic food. Foods 2020, 9, 197. [CrossRef]

9. Sultan, P.; Tarafder, T.; Pearson, D.; Henryks, J. Intention-behaviour gap and perceived behavioural control-behaviour gap in theory of planned behaviour: Moderating roles of communication, satisfaction and trust in organic food consumption. Food Qual. Prefer. 2000, 81, 103838. [CrossRef]

10. Sun, Y.; Wang, S. Understanding consumers' intentions to purchase green products in the social media marketing context. Asia Pac. J. Mark. Logist. 2019, 32, 860-878. [CrossRef]

11. Wang, S.; Lin, S.; Li, J. Exploring the effects of non-cognitive and emotional factors on household electricity saving behavior. Energy Policy 2018, 115, 171-180. [CrossRef]

12. Zhou, Y.; Thøgersen, J.; Ruan, Y.; Huang, G. The moderating role of human values in planned behavior: The case of Chinese consumers' intention to buy organic food. J. Consum. Mark. 2013, 30, 335-344. [CrossRef]

13. Thøgersen, J.; Jørgensen, A.K.; Sandager, S. Consumer Decision Making Regarding a "Green" Everyday Product. Psychol. Mark. 2012, 29, 187-197. [CrossRef]

14. Thøersen, J.; Zhou, Y. Chinese consumers' adoption of a "green" innovation-The case of organic food. J. Mark. Manag. 2012, 28, 313-333. [CrossRef] 
15. Golob, U.; Kos Koklic, M.; Podnar, K.; Zabkar, V. The role of environmentally conscious purchase behaviour and green scepticism in organic food consumption. Br. Food J. 2018, 120, 2411-2424. [CrossRef]

16. Bandura, A. Social Cognitive Theory: An Agentic Perspective. Annu. Rev. Psychol. 2001, 52, 1-26. [CrossRef] [PubMed]

17. Burke, M.A.; Young, H.P. Social norms. In Handbook of Social Economics; Elsevier: Amsterdam, The Netherlands, 2011; pp. 311-338.

18. Abrahamse, W.; Steg, L. Social influence approaches to encourage resource conservation: A meta-analysis. Glob. Environ. Chang. 2013, 23, 1773-1785. [CrossRef]

19. Miller, D.T.; Prentice, D.A. Changing Norms to Change Behavior. Annu. Rev. Psychol. 2016, 67, 339-361. [CrossRef] [PubMed]

20. Nowak, A.; Vallacher, R.R.; Bui-Wrzosinska, L.; Coleman, P.T. Attracted to conflict: A dynamical perspective on malignant social relations. In Understanding Social Change: Political Psychology in Poland; Nova Science Pub. Inc.: Hauppauge, NY, USA, 2006; pp. 33-49.

21. White, K.; Habib, R.; Hardisty, D.J. How to SHIFT consumer behaviors to be more sustainable: A literature review and guiding framework. J. Mark. 2019, 83, 22-49. [CrossRef]

22. Dreezens, E.; Martijn, C.; Tenbült, P.; Kok, G.; De Vries, N.K. Food and values: An examination of values underlying attitudes toward genetically modified- and organically grown food products. Appetite 2005, 44, 115-122. [CrossRef]

23. Puska, P. Does Organic Food Consumption Signal Prosociality?: An Application of Schwartz's Value Theory. J. Food Prod. Mark. 2019, 25, 207-231. [CrossRef]

24. Fleșeriu, C.; Cosma, S.A.; Bocăneț, V. Values and Planned Behaviour of the Romanian Organic Food Consumer. Sustainability 2020, 12, 1722. [CrossRef]

25. Schwartz, S.H. Are There Universal Aspects in the Structure and Contents of Human Values? J. Soc. Issues 1994, 50, 19-45. [CrossRef]

26. Hofstede, G. Culture's Consequences: Comparing Values, Behaviors, Institutions and Organizations Across Nations, 2nd ed.; Sage Publications: Thousand Oaks, CA, USA, 2001; ISBN 1452207933.

27. Inglehardt, R. Modernization and Postmodernization: Cultural, Economic, and Political Change in 43 Societies; Princeton University Press: Princeton, NJ, USA, 1997.

28. Stern, P.C.; Dietz, T. The Value Basis of Environmental Concern. J. Soc. Issues 1994, 50, 65-84. [CrossRef]

29. Hansen, T.; Sørensen, M.I.; Eriksen, M.L.R. How the interplay between consumer motivations and values influences organic food identity and behavior. Food Policy 2018, 74, 39-52. [CrossRef]

30. Rokeach, M. The Nature of Human Values; Free Press: New York, NY, USA, 1973.

31. Schwartz, S.H. Universals in the content and structure of values: Theoretical advances and empirical tests in 20 countries. Adv. Exp. Soc. Psychol. 1992, 25,1-65. [CrossRef]

32. Rasool, S.; Shakur, M.M.A.; Mughal, Y.H.; Awang, Z. Validating a measure for altruistic self towards the responsible plate food consumption: A mix method approach. Int. J. Bus. Soc. 2019, 20, 211-228.

33. Chen, M.F. Selecting environmental psychology theories to predict people's consumption intention of locally produced organic foods. Int. J. Consum. Stud. 2020. [CrossRef]

34. Lee, H.J. Does consumption of organic foods contribute to Korean consumers' subjectivewell-being? Sustainability 2019, 11, 5496. [CrossRef]

35. Thøgersen, J.; Zhou, Y.; Huang, G. How stable is the value basis for organic food consumption in China? J. Clean. Prod. 2016, 134, 214-224. [CrossRef]

36. Hempel, C.; Hamm, U. How important is local food to organic-minded consumers? Appetite 2016, 96, 309-318. [CrossRef]

37. Miranda-de la Lama, G.C.; Estévez-Moreno, L.X.; Sepúlveda, W.S.; Estrada-Chavero, M.C.; Rayas-Amor, A.A.; Villarroel, M.; María, G.A. Mexican consumers' perceptions and attitudes towards farm animal welfare and willingness to pay for welfare friendly meat products. Meat Sci. 2017, 125, 106-113. [CrossRef]

38. Caracciolo, F.; Cicia, G.; Del Giudice, T.; Cembalo, L.; Krystallis, A.; Grunert, K.G.; Lombardi, P. Human values and preferences for cleaner livestock production. J. Clean. Prod. 2016, 112, 121-130. [CrossRef]

39. Sonoda, Y.; Oishi, K.; Chomei, Y.; Hirooka, H. How do human values influence the beef preferences of consumer segments regarding animal welfare and environmentally friendly production? Meat Sci. 2018, 146, 75-86. [CrossRef] [PubMed] 
40. Jacobs, K.; Petersen, L.; Hörisch, J.; Battenfeld, D. Green thinking but thoughtless buying? An empirical extension of the value-attitude-behaviour hierarchy in sustainable clothing. J. Clean. Prod. 2018, 203, 1155-1169. [CrossRef]

41. Thøgersen, J.; de Barcellos, M.D.; Perin, M.G.; Zhou, Y. Consumer buying motives and attitudes towards organic food in two emerging markets: China and Brazil. Int. Mark. Rev. 2015, 32, 389-413. [CrossRef]

42. Ajzen, I. The theory of planned behavior. Organ. Behav. Hum. Decis. Process. 1991, 50, 179-211. [CrossRef]

43. Oreg, S.; Katz-Gerro, T. Predicting proenvironmental behavior cross-nationally: Values, the theory of planned behavior, and value-belief-norm theory. Environ. Behav. 2006, 38, 462-483. [CrossRef]

44. Teng, C.C.; Wang, Y.M. Decisional factors driving organic food consumption: Generation of consumer purchase intentions. Br. Food J. 2015, 117, 1066-1081. [CrossRef]

45. Pearson, D.; Henryks, J.; Jones, H. Organic food: What we know (and do not know) about consumers. Renew. Agric. Food Syst. 2011, 26, 171-177. [CrossRef]

46. Vermeir, I.; Verbeke, W. Sustainable food consumption: Exploring the consumer "attitude-behavioral intention" gap. J. Agric. Environ. Ethics 2006, 19, 169-194. [CrossRef]

47. Bandura, A. Self-efficacy mechanism in human agency. Am. Psychol. 1982, 37, 122-147. [CrossRef]

48. Asif, M.; Xuhui, W.; Nasiri, A.; Ayyub, S. Determinant factors influencing organic food purchase intention and the moderating role of awareness: A comparative analysis. Food Qual. Prefer. 2018, 63, 144-150. [CrossRef]

49. Magnusson, M.K.; Arvola, A.; Koivisto Hursti, U.K.; Åberg, L.; Sjödén, P.O. Attitudes towards organic foods among Swedish consumers. Br. Food J. 2001, 103, 209-227. [CrossRef]

50. Al-Swidi, A.; Huque, S.M.R.; Hafeez, M.H.; Shariff, M.N.M. The role of subjective norms in theory of planned behavior in the context of organic food consumption. Br. Food J. 2014, 116, 1561-1580. [CrossRef]

51. Chen, M.F. Consumer attitudes and purchase intentions in relation to organic foods in Taiwan: Moderating effects of food-related personality traits. Food Qual. Prefer. 2007, 18, 1008-1021. [CrossRef]

52. Tarkiainen, A.; Sundqvist, S. Subjective norms, attitudes and intentions of Finnish consumers in buying organic food. Br. Food J. 2005, 107, 808-822. [CrossRef]

53. de Leeuw, A.; Valois, P.; Ajzen, I.; Schmidt, P. Using the theory of planned behavior to identify key beliefs underlying pro-environmental behavior in high-school students: Implications for educational interventions. J. Environ. Psychol. 2015, 42, 128-138. [CrossRef]

54. Yadav, R.; Pathak, G.S. Young consumers' intention towards buying green products in a developing nation: Extending the theory of planned behavior. J. Clean. Prod. 2016, 135, 732-739. [CrossRef]

55. Fishbein, M.; Ajzen, I. Strategies of Change: Active Participation; Addison-Wiley Publishing Company: Boston, MA, USA, 1975; ISBN 0201020890.

56. Warshaw, P.R.; Davis, F.D. Disentangling behavioral intention and behavioral expectation. J. Exp. Soc. Psychol. 1985, 21, 213-228. [CrossRef]

57. Konerding, U. Formal models for predicting intentions in dichotomous choice situations. Methods Psychol. Res. Online 1999, 4, 1-32.

58. Fishbein, M.; Ajzen, I. Attitude theory and the attitude-behavior relation. In New Directions in Attitude Measurement; Krebs, D., Schmidt, P., Eds.; De Gruyter: Berlin, Germany, 1993; pp. 41-57. ISBN 3110138719. (alk. paper).

59. Birch, D.; Memery, J. Tourists, local food and the intention-behaviour gap. J. Hosp. Tour. Manag. 2020, 43, 53-61. [CrossRef]

60. Mittal, V.; Kamakura, W.A. Satisfaction, repurchase intent, and repurchase behavior: Investigating the moderating effect of customer characteristics. J. Mark. Res. 2001, 38, 131-142. [CrossRef]

61. Olsen, S.O.; Grunert, K.G. The role of satisfaction, norms and conflict in families' eating behaviour. Eur. J. Mark. 2010, 44, 1165-1181. [CrossRef]

62. Onel, N. Pro-environmental Purchasing Behavior of Consumers: The Role of Norms. Soc. Mar. Q. 2017, 23, 103-121. [CrossRef]

63. Michaelidou, N.; Hassan, L. New advances in attitude and behavioural decision-making models. J. Mark. Manag. 2014, 30, 519-528. [CrossRef]

64. Goldsmith, E.B.; Goldsmith, R.E. Social influence and sustainability in households. Int. J. Consum. Stud. 2011, 35, 117-121. [CrossRef] 
65. Du, S.; Bartels, J.; Reinders, M.; Sen, S. Organic consumption behavior: A social identification perspective. Food Qual. Prefer. 2017, 62, 190-198. [CrossRef]

66. Sandhu, Y.A.; Perumal, S.A.L.; Fauzi, W.I.M. The predictors and consequences of personal norms in context of organic food among Pakistani consumers. Int. J. Financ. Res. 2019, 10, 314. [CrossRef]

67. Aertsens, J.; Verbeke, W.; Mondelaers, K.; van Huylenbroeck, G. Personal determinants of organic food consumption: A review. Br. Food J. 2009, 111, 1140-1167. [CrossRef]

68. Rodriguez-Gonzalez, P.T.; Rico-Martinez, R.; Rico-Ramirez, V. Effect of feedback loops on the sustainability and resilience of human-ecosystems. Ecol. Modell. 2020, 426, 109018. [CrossRef]

69. Sosis, R. The building blocks of religious systems: Approaching religion as a complex adaptive system. In Evolution, Development and Complexity; Springer: Cham, Switzerland, 2019; pp. 421-449.

70. Anderson, K.; Ahn, S.; Lee, S. Social learning's effect on absenteeism: The effect of project turnover. In Proceedings of the Construction Research Congress 2014: Construction in a Global Network, Atlanta, GA, USA, 19-21 May 2014; pp. 199-208.

71. International Social Survey Programme: Environment III-ISSP 2010; GESIS-Leibniz-Institut für Sozialwissenschaften: Mannheim, Germany, 2012; ZA No. 5500.

72. European Social Survey Round 5 Data 2010; ESS ERIC: London, UK, 2010; Data file edition 3.2.

73. D'Orazio, M. Statistical Matching and Imputation of Survey Data with StatMatch; Italian National Institute of Statistics: Rome, Italy, 2017.

74. D’Orazio, M. StatMatch: Statistical Matching or Data Fusion. R Package Version 1.3.0. Available online: https://rdrr.io/cran/StatMatch/ (accessed on 10 March 2020).

75. Team, R.C. R: A language and Environment for Statistical Computing; R Foundation for Statistical Computing: Vienna, Austria, 2019.

76. Rosseel, Y. lavaan: An R package for structural equation modeling. R package version 0.5-15. J. Stat. Softw. 2012, 48, 1-36. [CrossRef]

77. Wickham, H. ggplot2: Elegant Graphics for Data Analysis, 2nd ed.; Springer: New York, NY, USA, 2016.

78. Pedersen, T.L. ggraph: An Implementation of Grammar of Graphics for Graphs and Networks. R Package Version 2.0.0. Available online: https://ggraph.data-imaginist.com/ (accessed on 10 March 2020).

79. Bivand, R.S.; Wong, D.W.S. Comparing implementations of global and local indicators of spatial association. TEST 2018, 27, 716-748. [CrossRef]

80. Bivand, R.S.; Pebesma, E.; Gómez-Rubio, V. Applied Spatial Data Analysis with R, 2nd ed.; Springer: New York, NY, USA, 2013; ISBN 9781461476184.

81. Wickham, H.; Francois, R.; Henry, L.; Müller, K. Dplyr: A Grammar of Data Manipulation. R Package Version 0.8.4. Available online: https://dplyr.tidyverse.org/ (accessed on 10 March 2020).

82. D'Orazio, M.; Di Zio, M.; Scanu, M. Statistical Matching: Theory and Practice; John Wiley \& Sons: West Sussex, UK, 2006.

83. Schwartz, S.H. A proposal for measuring value orientations across nations. Quest. Packag. Eur. Soc. Surv. 2003, 259, 261.

84. Gower, J.C. A General Coefficient of Similarity and Some of Its Properties. Biometrics 1971, $27,857-871$. [CrossRef]

85. Marcoulides, G.A.; Schumacker, R.E. Advanced Structural Equation Modeling: Issues and Techniques; Lawrence Erlbaum Associates Inc.: New Jersey, NJ, USA, 1996.

86. Anderson, J.C.; Gerbing, D.W. Structural Equation Modeling in Practice: A Review and Recommended Two-Step Approach. Psychol. Bull. 1988, 103, 411-423. [CrossRef]

87. Hair, J.F.; Sarstedt, M.; Hopkins, L.; Kuppelwieser, V.G. Partial least squares structural equation modeling (PLS-SEM): An emerging tool in business research. Eur. Bus. Rev. 2014, 26, 106-121. [CrossRef]

88. Nunnally, J.; Bernstein, I. Psychometric Theory, 3rd ed.; McGraw-Hill: New York, NY, USA, 1994; ISBN1 007047849X. ISBN2 9780070478497.

89. Sekaran, U.; Bougie, R. Research Method for Business: A Skill Building Approach, 6th ed.; John Wiley \& Sons: New York, NY, USA, 2013; ISBN 978-1-119-94225-2.

90. Hu, L.T.; Bentler, P.M. Cutoff criteria for fit indexes in covariance structure analysis: Conventional criteria versus new alternatives. Struct. Equ. Model. 1999, 6, 1-55. [CrossRef]

91. Schwartz, S.H. Individualism-collectivism: Critique and Proposed Refinements. J. Cross. Cult. Psychol. 1990, 21, 139-157. [CrossRef] 
92. Willer, H.; Schlatter, B.; Trávníček, J.; Kemper, L.; Lernoud, J. The World of Organic Agriculture—Statistics and Emerging Trends 2020; FAO: Rome, Italy, 2020.

93. Lampert, M.; Metaal, S.; Liu, S.; Gambarin, L. Global Rise in Environmental Concern; Glocalities International B.V.: Amsterdam, The Netherlands, 2019.

(C) 2020 by the authors. Licensee MDPI, Basel, Switzerland. This article is an open access article distributed under the terms and conditions of the Creative Commons Attribution (CC BY) license (http://creativecommons.org/licenses/by/4.0/). 